\title{
The Balance of Interests Theory and the Fourth Amendment: A Selective Analysis of Supreme Court Action Since Camara and See
}

\author{
Peter S. Greenberg*
}

I.

\section{INTRODUCTION}

In Camara v. Municipal Court ${ }^{1}$ and its companion case, See v. City of Seattle, ${ }^{2}$ the United States Supreme Court used a balance of interests analysis to decide fourth amendment issues; the implications of this approach reach beyond the immediate problems presented in Camara and See. Camara-See examined the role of the fourth aniendment in "administrative" searches. ${ }^{3}$ Eight years earlier, in Frank v. Maryland, ${ }^{4}$ the Court faced the same question in a case involving a warrantless search by a Baltimore City Health Department inspector. There the Court adopted the premise that a governmental intrusion is either a search within the meaning of the fourth amendment, requiring the traditional fourth amendment protection devices of warrant and probable cause, ${ }^{5}$ or is a "search" outside the scope of the fourth amendment, requiring no attendant protections. ${ }^{6}$ The Frank Court found the ad-

* Assistant Professor of Law, Case Western Reserve University; B.A. 1965, LL.B. 1968, University of Pennsylvania; Member, Pennsylvania Bar.

1. 387 U.S. 523 (1967).

2. 387 U.S. 541 (1967).

3. Camara involved an attempted inspection by an inspector of San Francisco's Department of Public Health, Division of Housing Inspection. 387 U.S. at 525-26. See extended Camara to nonresidential properties, striking down an attempt by a Seattle Fire Department inspector to examine a warehouse. 387 U.S. at 541, 542-46. The inspectors were looking for housing code and fire code violations, respectively.

4. 359 U.S. 360 (1959).

5. Normally, when a governmental intrusion is within the fourth amendment, the government, except in certain enumerated situations, see note 8, infra, needs the authority of a search warrant signed by an independent and neutral judicial officer to make such an intrusion. See Coolidge v. New Hanipshire, 403 U.S. 443 (1971). In order to obtain the warrant, it is necessary for governmental agents to establish a sufficient level of probability that the thing for which they were looking is in fact in the place to be searched.

6. 359 U.S. at 372-73. Although the Court discussed the probability protec- 
ministrative search to be in the latter category. While this all-or-nothing view of fourth amendment protections has not been applied without exception, the Court has abandoned it only in situations believed to call for immediate police action to avoid injury, destruction of evidence, or escape. ${ }^{7}$ These exceptional circumstances necessitate balancing governmental necessity agamst citizen privacy, and result in abandoninent of one traditional fourth amendment protection device-the warrant requirement. The significance of Camara-See lies in the Court's recognition for the first time that a balancing of interests approach can be applied to governinental intrusion situations not involving exigent circumstances and that this balance can be reflected in a inodification of fourth amendment protection techniques rather than their abandonment.

The Court held in Camara-See that the governmental intrusion accompanying an administrative search is within the scope of the fourth annendment's protection and requires the authorization of a search warrant; 8 however, a magistrate may issue such a warrant on less than probable cause. ${ }^{9}$ After stripping away some of the less logical

tions provided by the Baltimore ordinance, id. at $366-67$, it gave some indication that administrative inspections are not constitutionally limited to situations where there are valid grounds to suspect the existeuce of nuisance. LaFave, Administrative Searches and the Fourth Amendment, 1967 SuP. CT. REv. 1, 6 [hereinafter cited as LaFave, Administrative Searches].

7. The warrant requirenent traditionally has been excused where necessary to prevent the loss or destruction of evidence, e.g., Schmerber v. California, 384 U.S. 757 (1966) (blood test for intoxication); Carroll v. United States, 267. U.S. 132 (1925) (establishing the moveable vehicle exception, see notes 110-14 infra and accompanying text); where the search is incident to a lawful arrest, e.g., Chimel v. California, 395 U.S. 752 (1969); and where the police are in hot pursuit of a suspect, e.g., Warden v. Hayden, 387 U.S. 294 (1967). There is some question as to the continued viability of two other possible exceptions: searches pursuant to entry on premises in the hope of nuaking an arrest and searches which require no entry. Sec L. HALL, Y. Kamisar, W. LaFave \& J. Israel, Modern Cruminal Procedure 267-68, 269-70 (3d ed. 1969) [hereinafter cited as HALL ET AL.].

8. 387 U.S. at 534. The Court cmphasized that nuost citizens would permit inspections of their property without a warrant. Id. at 539. Proper consent, of course, has always relieved the warrant and probable cause requirements. See, e.g., HALL ET AL., supra note 7, at 291-92. However, the emphasis on consent in Camara apparently has led sone courts to believe that the standard for deterinining whether consent is valid in the traditional criminal search case, sec, e.g., Bunnper v. North Carolina, 391 U.S. 543 (1968), is to be replaced by a substantially more relaxed rule in administrative search cases. See United States v. Thriftimart, Inc., 429 F.2d 1006, 1010 (9th Cir. 1970), cert. denied, 400 U.S. 926 (1970) (any matter of consent "no nuatter how casual"); United States v. Hammond Knitting Co., 413 F.2d 608 (5th Cir. 1969), cert. denied, 396 U.S. 1002 (1970). In addition, there is sonie support for a doctrine of "implied consent" in certain cases. See notes 61-62 infra and accompanying text.

9. 387 U.S. at 534-39. 
supports offered by the Court, ${ }^{10}$ one commentator concludes that Camara-See should properly be viewed as based on:

(1) the mability to accomplish an acceptable level of code enforcement under the traditional probable cause test; and (2) the relatively mimor invasion of personal privacy and dignity that attends periodic and area inspection programs. ${ }^{11}$

Camara-See created limited change in the warrant requireinent simce, in theory at least, the exceptions to the warrant requirement generally involve situations in which obtaining a warrant is sufficiently impractical so as to frustrate justifiable government aims. ${ }^{12}$ The more striking innovation involves the probability requirement. Traditional probable cause requires a definitionally undeterminable, but nonetheless substantial amount of information that a specific item (or items) is in a specific place. ${ }^{13}$ Camara-See modifies this for administrative searches. ${ }^{14}$ Information about specific ordinance violations or conditions in specific buildings is deemed unnecessary in such searches, ${ }^{15}$ and the warrant apparently can be based on "such factors as the passage of time [since the previous inspection], the nature of the building, or the condition of the entire area ..."16 The citizen is now en-

10. LaFave, Administrative Searches, supra note 6, at 13-18.

11. Id. at 20.

In Professor LaFave's view, enforcement was impossible as a practical matter under the traditional probable cause test because most housing code violations occur within private premises and cannot be detected from outside, most serious violations are noticeable only in the aggregate, and a relatively small number of complaimts, many anonymous, are received. Id. at 15-16.

Professor LaFave considered the privacy mvasion to be relatively limited because the inspection would be direeted at public utility and sanitation systems. These facilities can be examined quickly without rummaging through personal possessions and without seizing evidence. In addition, the typical routine inspection does not stigmatize an individual as a subject of police interest, and does not require surprise. Id. at $18-19$.

12. See note 7 supra. While excusing the warrant requirement does not relieve the government of the need to show probable cause, in fact, the government may have a lesser burden when a warrant is issued for the search. See Umited States v. Ventresca, 380 U.S. 102, 106-07 (1965); Jones v. United States, 362 U.S. 257, 270-71 (1960). The rules governing the moveable vehicle exception, however, have not consistently responded to realistic notions of the governmental burden, see notes 110-14 infra and accompanying text, and in this area and others there is room to use the balancing of interests approach to better accommodate government aud citizens in the warrant procedure. See, e.g., notes 53-57 infra and accompanying text.

13. [T] he facts and circumstances within their [the police's] knowledge and of which they had reasonably trustworthy information sufficient in themselves to warrant a man of reasonable caution im the belief that [the offense was being committed].

Carroll v. United States, 267 U.S. 132, 162 (1925).

14. 387 U.S. at $538-39,545$.

15. Id.

16. LaFave, Administrative Searches, supra note 6 , at 13. 
titled to as much protection as feasible, in light of governmental necessity, froin governmental imtrusions not traditionally searclies or seizures within the fourth amendment. ${ }^{17}$

Although there lias been some feeling that the particular compromise in Camara-See provides inadequate citizen protection ${ }^{18}$ the significance of the decision is in the approach taken by the Court. Faced with substantial practical problems in carrying over the traditional fourth amendment protections to the administrative search situation, the Court nevertheless chose to give the citizen some protection rather than to dismiss the fourth amendment claim completely. Although the Court's solution in Camara-See results in less citizen protection than might be desired, the Camara warrant is preferable to no protection at all. ${ }^{19}$ Camara-See after all, was a starting point; presumably more miaginative uses of the theory, providing fuller protection and minimal harm to the government's imterests, would develop in future cases.

The stop-and-frisk cases $^{20}$ provided an initial indication that the Court would continue application of an analysis consistent with the theoretical bases of Camara-See. ${ }^{21}$ Previously, stop-and-frisk cases depended on determining whether or not a stop was an "arrest" and a frisk was a "search"; depending on these characterizations, the citizen either received full protection or none at all. ${ }^{22}$ In Terry v. Ohio, the Court rejected this all-or-nothing concept, opting instead for a iniddle ground-the balance of interests approach. The Court felt that the very nature of the street encounter of necessity excused the warrant

17. See Terry v. Ohio, 392 U.S. 1, 17-18 n.15 (1968). But cf. Wyman v. James, 400 U.S. 309 (1971), discussed at notes 65-107 infra and accompanying text.

The governmental invasion must, of course, intrude upon a citizen's reasonable expectation of privacy. Katz v. United States, 389 U.S. 347 (1967). Reasonable expectation of privacy is a significant issue in the "implied consent" cases, where the search arguably can be anticipated in advance by a citizen who has entered into a regulated business or occupation. See notes 62-64 infra and accompanying text.

18. See, e.g., Comment, Constitutional Law-Administrative Searches and the Fourth Amendment: The Definition of "Probable Cause" in Camara v. Municipal Court of the City and County of San Francisco, 36 U. Mo.-K.C. L. REV. 111, 120 (1968); cf. LaFave, Administrative Searches, supra note 6, at 27-35, suggesting that notice and hearing before the search takes place would more fully protect the right of privacy than would requiring a warrant.

19. See notes 53-57 infra and accompanying text, discussing the role of the warrant as a check on harassment and overzealous enforcement.

20. Terry v. Ohio, 392 U.S. 1 (1968); Sibron v. New York, 392 U.S. 40 (1968). See also Davis v. Mississippi, 394 U.S. 721 (1969).

21. The stop-and-frisk cases are completely consistent with the textual analysis of Camara-See. See LaFave, "Street Encounters" and the Constitution: Terry, Sibron, Peters, and Beyond, 67 Mich. L. Rev. 40, 55-59 (1968).

22. Terry v. Ohio, 392 U.S. at 17-18 n.15 (1968). 
requirement. ${ }^{23}$ Allowing personal detention and soine type of intrusion on less than traditional probable cause was the real problem.

Citing Camara, the Court in Terry held that the type of limited detention involved in stop-and-frisk was permissible with a lesser level of probability that the suspect is armed than traditional probable cause would require. ${ }^{24}$ Stop-and-frisk was permissible if merely a reasonable belief of danger existed. ${ }^{25}$ This reasonable belief, like probable cause, can be adequately defimed only by considerable reference to specific cases. Years of appellate decisions involving traditional probable cause give us a reasonably accurate notion of when it is present, even if precise definition is inpossible. For present purposes, we can assume that reasonable belief will usually involve the same type of probability determination, but the standard will be satisfied by a substantially less complete factual construct. In short, although a police officer inust rely on "specific and articulable facts," is justified even though those facts point at a given imdividual with considerably less specificity than would be required to constitute traditional probable cause.

It is unnecessary to discuss the stop-and-frisk cases in depth to appreciate their inrportance to a balance of interests analysis of fourth amendment protection. In addition to upholding the Camara-See balance of interests approach, Terry and its companion cases expressly authorize a new probability standard, falling between the Camara-See standard-presumably far too loose to be applied in the criminal search

23. Id. at 20. Historically, probable cause justifies an arrest without a warrant. See, e.g., Draper v. United States, 358 U.S. 307, 310-11 (1959).

24. 392 U.S. at 27.

25. Id. It is not clear whether there must be an independent behief that justifies the frisk, or whether the frisk is justified by the belief that originally permitted the stop. Compare 392 U.S. 1, 32-34 (Harlan, J., concurring) with 392 U.S. 1, 34-35 (White, J., concurring) and with Sibron v. New York, 392 U.S. 40, 62-65.

26. Terry v. Ohio, 392 U.S. 1, 21 (1968). But cf. Adams v. Williams, 407 U.S. 143 (1972). Williams involved a stop-and-frisk (followed by a full search incident to an arrest based on probable cause supposedly gained as a result of the frisk) based on an unverified tip, rather than on the officer's personal observations. Support for the informant's past rehability was sketchy. Furthermore, the source of the informant's information was never ascertained. The Court previously had carefully scrutinized warrants based on unverified tips. See Spinelli v. United States, 393 U.S. 410 (1969); Aguilar v. Texas, 378 U.S. 108 (1964). The standard for determining probable cause in this situation was not met, but the Court found a lesser "indicia of rehiability" sufficient to meet the probability requirements of stop-and-frisk. 407 U.S. at 147. This seems sound in theory, but questionable as applied in Williams. Terry made clear that probability was not sufficient if based on the unsupported "bunch" of the officer. 392 U.S. at 27. But allowing reliance on the informant in Williams provides no guarantee that the officer's actions are not based on an unsupported hunch of the informant, since apparently' no evidence indicating the source of the informant's knowledge is necessary. The anomalous result is that the informant's hearsay hunch may stand on firmer ground than the officer's first-person hunch. 
context-and the relatively strict standard of traditional probable cause. A balance of interests approach, then, theoretically demands a sliding scale of probability standard, varying with the level of intrusion in each type of situation. Ascertaining those probability gradations, however, creates serious practical difficulties. While judicial definition of probable cause and the lesser standard of reasonable belief may be feasible, neither test is at all precise, and a delineation of intermediate categories would most likely create additional confusion. Furthermore, traditional probable cause and the new standards used in Camera-See and Terry should provide sufficient alternatives to deal with virtually all situations.

Unfortunately, the extent to which the Court thus far has applied this balancing approach has been inadequate in both ascertaining the proper reach of Camera-See and reexamining traditional rules in other governmental intrusion situations. The following discussion addresses these inadequacies by analyzing recent significant decisions in which the balancing theory should have played a major role. While not a comprehensive survey of all potential applications of Camdra-See, this discussion indicates the desirabihty of expanded use of the balancing concept.

II.

\section{LICENSING AND REgULATORY SEARCHES}

A logical place to commence examination of the Court's use of the balance of interests approach to the fourth amendment is the field of the administrative search where the theory first gained major apphcation. The phrase "administrative search" encompasses governmental investigatory intrusions that are not the traditional searches for criminal evidence; there is no single type of "administrative search." For example, in See, the Court pointed out a situation different from the routine area inspection it was immediately concerned with:

We do not in any way imply that business premises may not reasonably be inspected in many more situations than private homes, nor do we question such accepted regulatory techniques as licensing ... inspections prior to operating a business or marketing a product. Any constitutional challenge to such programs can only be resolved ... on a case-by-case basis under the general Fourth Amendinent standard of reasonableness. ${ }^{27}$

This reservation of the licensing and regulatory search issues is of particular interest because of its potential for broad exception to the $\mathrm{Ca}$ mara-See rule. Initially, the Court's reference to "prior" regulatory or licensing inspections appeared to limit significantly such exception. In

27. 387 U.S. at $545-46$. 
fact, if so limited, such exceptions remain consistent with a balance of interests approach. A single inspection at the time a new product or business is about to become available to the public is motivated solely by the appearance of the enterprise in question and is narrowly directed. The lesser standard of probable cause for such imvestigations is met by the newness of the product or business and because it has been administratively determined to be of a type requiring prior monitoring. ${ }^{28}$ With "probability" established independently of the investigator's beliefs, and the potential for harassinent or abuse virtually nonexistent since the right to inspect ends when the enterprise opens to the public, a warrant procedure can be dispensed with since it would serve no useful purpose. A balance between governmental interests and citizen privacy is thus einbodied in, not excluded from, this narrow exception.

Commentators did not read the Court's dictum, however, as strictly limited to administrative and regulatory searches not factually similar to those in Camara-See. ${ }^{29}$ The Court confirmed this position with two decisions that approve regulatory searches of licensed business which did not conform to the Camara-See restrictions. ${ }^{30}$ These decisions fail to use the flexible possibilities of the balancing test, and raise some doubts about the Court's continued commitment to the balancing of interests approach.

Colonnade Catering Corp. v. United States dealt with the inspection by Internal Revenue Service Agents of a business holding the federal occupational tax stamp required of liquor retailers. ${ }^{31}$ An I.R.S. agent originally entered petitioner's catering establishment as a guest at a party, and observed a possible federal excise tax law violation. Federal agents subsequently returned and found another party in progress, with liquor being served. Without obtaining consent, the agents inspected the cellar, then asked the manager to open a locked storeroom.

28. When a new business opens, or when a new product is marketed, there will be no facts generally available about the enterprise. Thus, in addition to licensing, at least some investigation and inspection is justified at this point to minimize the risk of widespread public injury that otherwise could take place before the dangerousness of the enterprise is detected. But under these circumstances, requiring the government to produce specific facts about given new businesses or products before the business is open or the product on the market will make regulation virtually impossible. Thus, in order to permit the government to fulfill its investigatory duties, sufficient probable cause must be deemed to exist simply because the new enterprise is an unknown quantity.

29. See Note, 1972 WASH. U. L.Q. 313, 327-28 (1972).

30. United States v. Biswell, 406 U.S. 311 (1972); Colonnade Catering Corp. v. United States, 397 U.S. 72 (1970). See also Wyınan v. James, 400 U.S. 309 (1971).

31. 26 U.S.C. $\$ 5121(a)$ (1971). 
The manager stated that petitioner's president was the only person authorized to open the storeroom. When the president arrived he refused to open the room for the agents. Eventually the agents broke the lock and entered.

The agents' entry into the storeroom was authorized, argued the government, under 26 U.S.C. sections 5146 (b) and $7606,{ }^{32}$ neither of which required a warrant to accompany the intrusion. The Court accepted the government's contention that the absence of a warrant was not fatal to the legality of administrative searches specifically authorized by statute. ${ }^{33}$

The Court did not explain why the warrant was not constitutionally required; instead it relied on a general discussion of legislative authorizations of warrantless liquor imspections dating back to colonial days. ${ }^{34}$ The balance of interest analysis reasonably to be expected after Camara-See was completely lacking.

This cursory treatment is at least partly explained by the fact that the Court struck down the search, holding that Congress had not authorized forcible entries in the enabling statutes. ${ }^{35}$ But the Court's ultimate conclusion on this point was rather oddly stated: "Where Congress has authorized inspection but made no rules governing the procedure that inspectors inust follow, the Fourth Amendinent and its various restrictive rules apply."36 This conclusion presumably ineans that the fourth amendment and its warrant requirement applies in situations where government agents seek to use tactics not specifically authorized by Congress. The obvious implication is that it is within the discretion of Congress to apply or not apply the fourth amendment, a postulate wholly inconsistent with the balance of interests theory of Camara-See and Terry. Once there is a governmental intrusion ${ }^{37}$ the

32. 26 U.S.C. \& 5146(b) (1971) provides:

The Secretary or his delegate may enter during business hours the premises (including places of storage) of any dealer for the purpose of inspecting or examining any records or other docunents required to be kept by such dealer under this chapter or regulations issued pursuant thereto and any distilled spirits, wines, or beer kept or stored by such dealer on such preinises.

26 U.S.C. \& 7606 (1971) provides:

(a) Entry during day.

The Secretary or his delegate may enter, in the daytime, any building or place where any articles or objects subject to tax are made, produced, or kept, so far as it inay be necessary for the purpose of cxamining said articles or objects.

(b) Entry at night.

When such premises are open at night, the Secretary or his delegate may enter them while so open, in the performance of his official duties.

33. 397 U.S. at 76-77.

34. Id. at 75-76.

35. Id. at 74,77 .

36. Id. at 77 .

37. Entry into an area open to the public, at a time when the public is admitted, 
fourth amendment "applies"; a fourth amendment issue lias at least been raised, and the proper inquiry is how it is to be resolved considering governmental needs and the protections due the citizen.

Colonnade, however, can be viewed as falling within a balancing analysis. Liquor dealers subjected to warrantless inspection under Colonnade are not left coinpletely bereft of protections normally expected under the fourth amendment. The statutes themselves limit to solne extent the permissible times of entry and the types of premises that may be entered. In addition, the statutes to some extent define and limit the scope of the search by establishing the objects or conditions for which agents may inspect. Arguably, then, the statutes largely replace a warrant and, since these inspections involve relatively limited types of privacy invasions, provide sufficient protections to satisfy the needs of the fourth amendment. ${ }^{38}$ Accepting this interpretation, the Court's statement that "the Fourth Amendment and various restrictive rules apply" only where Congress has inade no rules governing inspection procedure makes more sense: Colonnade simply means that in those situations in which Congress has not by statute provided sufficient protections to satisfy the fourth amendment, the Court will use the traditional protections formulated in prior cases. Here, for example, at least some form of warrant was ultimately deeined necessary. ${ }^{30}$

Conspicuously absent in the above interpretation, however, is an explanation of why it is proper under a balance of interests theory to dispense with the warrant and the additional protections that may be gamed froin its use. The complete absence of any probability requirement is also troublesome. Subsequent to Colonnade, the Court at least obliquely addressed itself to these matters in United States v. Biswell. $^{40}$

Biswell involved the statutory authority to enter and imspect created under the Gun Control Act of 1968.11 Respondent, a federaily li-

presumably violates no reasonable expectation of privacy under Katz v. United States, 389 U.S. 347 (1967).

38. See United States v. Hofbrauhaus of Hartford, 313 F. Supp. 544, 548 (D. Conn. 1970).

39. It is arguable that the implementation of innovative fourth amendment protections in general should be legislative, not judicial. See Note, 84 HARV. L. REv. 1465, 1474 (1971). Camara, however, illustrates that the Court is willing to substantially modify traditional techniques of fourth amendment protection where the balance of interests so requires, and it must be remembered that constitutional protection through what certainly resenbles judicial legislation is now well established in the confessions area under Miranda v. Arizona, 384 U.S. 436 (1966). See also note 165 infra and accompanying text.

40. 406 U.S. 311 (1972).

41. 18 U.S.C. $\S 921$ et seq. (1971). The statute provides in $\S 923(\mathrm{~g})$ : 
censed weapons dealer, was visited by a Treasury agent, who inspected respondent's books and requested admission to a locked storeroom containing guns. Respondent asked if the agent possessed a warrant, and was told by the agent that entry was proper without one. As a result, respondent admitted the agent to a storeroom containing weapons of a type respondent was not licensed to possess. The court of appeals overturned respondent's conviction, ${ }^{42}$ relying on Colonnade, but the Supreme Court reversed and reinstated the conviction.

In holding that the entry in Biswell was not "forcible," but was inade under lawful authority and thus not invalid under Colnnade, the Court was required to focus more fully on the constitutional validity of investigations authorized by statute. The Court's explicit mention of the need to fulfill the requirements of the fourth amendinent ${ }^{44}$ and its discussion of concerns of governmental necessity demonstrate that the Court was trying to strike the balance inandated in CamaraSee. The Court's analysis in striking that balance, however, was inadequate.

Each licensed importer, licensed manufacturer, licensed dealer, and licensed collector shall maintain such records of importation, production, shipment, receipt, sale or other disposition, of firearms and ammunition at such place, for such period, and in such form as the Secretary [of the Treasury] may by regulations prescribe. Such importers, manufacturers, dealers, and collectors shall make such records available for inspection at all reasonable times, and shall subimit to the Secretary such reports and information with respect to such records and the contents thereof as he shall by regulations prescribe. The Secretary may enter during business hours the premises (including places of storage) of any firearms or ammunitiou importer, manufacturer, dealer, or collector for the purpose of inspecting or examining (1) any records or documents required to be kept by such importer, manufacturer, dcaler, or collector under the provisions of this chapter or regulations issued under this chapter, and (2) any firearms or ammunition kept or stored by such importer, inanufacturer, dealer or collector at such premises. Upon the request of any State or any pohitical subdivision thereof, the Secretary may make available to such State or any political subdivision thereof, any information which he may obtain by reason of the provisions of this chapter with respect to the identification of persons within such State or political subdivision thereof, who have purchased or received firearms or ammunition together with a description of such firearms or aminunition.

42. United States v. Biswell, 442 F.2d 1189 (10th Cir. 1971).

43. 406 U.S. at 314-15. The Court reasoned that in rcquesting the storeowner to admit thein to the storeroom, the agents "were inerely asserting their statutory right," and thus the storeowner's acquiescence in the face of lawful authority presented no consent issue. Justice Douglas, who had authored the majority opinion in Colonnade, dissented, arguing that "a search conducted over the objection of the owner is 'forcible' whether or not violent means are used to effect the search." The withdrawal of the owner's objection after being informed of the agent's statutory authority thus was, to Justice Douglas, analogous to the "consent" struck down as inadequate in Bumper v. North Carolina, 391 U.S. 543 (1968) (conscnt resulting from police claim of authority under invalid or nonexistent warrant). 406 U.S. at 318-19.

44. 406 U.S. at $316,317$. 
The Court's first point in Biswell was that although federal firearms control was not "as deeply rooted in history" as the liquor control at issue in Colonnade, close scrutiny of firearm traffic is important in federal crime prevention efforts and federal assistance to state regulation efforts. The Court felt inspection is central to the regulatory scheme, "since it assures that weapons are distributed through regular channels and in a traceable manner and makes possible the prevention of sales to undesirable customers and the detection of the origin of particular firearms." 45 But to define the ends sought by firearms control, and to thus delineate a general need for soine regulation in this area, does not in itself dictate that fourth amendinent protections must give way. To assume otherwise renews an error which the Court made in Camara. ${ }^{40}$ The Court did not say, of course, that firearms control through broad inspection powers is more important than general enforcement of the criminal law which is subject to fourth amendment restrictions. If a distinction as to the citizen protection which will be accorded is to be made between these two situations, that distinction cannot be based on the importance of the goals sought im each instance. A more relevant argument is that relatively unencumbered inspection is of greater necessity in furthering the ends of firearms control than a like power is in the enforcement of criminal law. While evidence of crime can often be accumulated without use of the search power, effective regulation of licensed firearm businesses is impractical without resort to a broad inspection power. Defining the exact nature of governmental necessity, the extent of permissible privacy invasion and the requisite citizen protection, is the proper approach.

Biswell's response was to label inspection as "crucial" and to give the citizen only the protection provided by the statute, which included neither warrant nor probability requirement-a result foreshadowed by Colonnade. ${ }^{47}$ The Court noted that in See periodic inspections were

45. Id. at 315-16.

46. See LaFave, Administrative Searches, supra note 6, at 14-15. But cf. Professor LaFave's own comments in LaFave, "Street Encounters" and The Constitution: Terry, Sibron, Peters and Beyond, supra note 21, at 57 (proper police response should be judged by type of crime); Brinegar v. United States, 338 U.S. 160, 183 (1949) (Jackson, J., dissenting) (fourth amendment reasonableness should be based on relative severity of crime); Barrett, Personal Rights, Property Rights and the Fourth Amendment, 1960 Sup. CT. REv. 46, 63 (seriousness of the crime should be part of the balance). Perhaps, however, in situations like airplane hijackings where substantial loss of life may result from a single incident, and where there is no practical enforcement alternative, modification or constitutional protection is proper. See United States v. Lopez, 328 F. Supp. 1077 (E.D.N.Y. 1971). Although the enormity of the crime perhaps motivates the decision to reduce fourth amendment protection, considerations of enforcement alternatives may be more significant.

47. See notes 37-39 supra and accompanying text. The statute in Biswell, see 
sufficent as violations could not be readily concealed or corrected, and the warrant requirement would be "little if any threat to the effectiveness of the inspection system there at issue." ${ }^{48}$ But as to firearms control:

if inspection is to be effective and serve as a credible deterrent, unannounced, even frequent inspections are essential. In this context, the prerequisite of a warrant could easily frustrate inspection; and if the necessary flexibility as to time, scope and frequency is to be preserved, the protections afforded by a warrant would be negligible. ${ }^{49}$

While implicitly accepting the notion that regulation of licensed firearm busmesses is impractical, if not impossible, without resort to inspection power greater than that required by the police in general law enforcement situations, the Court failed to recognize that some form of warrant procedure and accoinpanying probability decision, perliaps different from that traditionally followed, could provide useful citizen protection without undermining the inspection program.

Real injury to the inspection program would occur only if the mechanics of obtaining the warrant and fulfilling its informational requirements are incoinpatible with enforcement. ${ }^{50}$ Definition of the place, scope and time of the search, information usually appearing in the warrant, is already provided by the enabling statute. All that remains is for the warrant affidavit to disclose some level of probability deemed necessary to justify the search. If it is impractical to require any level of probability to authorize the search in Biswell, the Court is correct, and a warrant requirement will add nothing useful to the procedure. However, the Court's explanation for abandonment of warrant protection-that in Camara-See situations, periodic, routine inspections are sufficient, but in the Biswell situation frequent, surprise inspections are necessary-provides dubious support, at best, for the conclusion in Biswell that any requirement of probability determination is impractical or unnecessary.

The warrant procedure need not necessarily make surprise impossible. The notion that a warrant procedure is imcompatible with a surprise search may be derived from the Camara reasoning indicating that the inspector normally would be expected initially to attempt to

note 41 supra, required dealers to keep records and to make them available for inspection "at all reasonable times." Government entries were limited to business hours, at the dealer's premises, and were for the purpose of inspecting records, firearms, or ammnnition at such premises. The statutes at issue in Colonnade, see note 32 supra, contained similar provisions.

48. 406 U.S. at 316.

49. Id.

50. See LaFave, Administrative Searches, supra note 6, at 11-12. 
gain entrance by consent, and a warrant would be obtained only if the property owner refused to allow him to enter. Thus the inspector's second visit presumably would be anticipated. This two-step procedure, however, is not essential. The inspector can obtain the warrant initially, as do police in traditional searches for criminal evidence. Since the warrant is issued ex parte, the subject of the inspection is not alerted to the inspector's impending arrival.

The mechanics of obtaining a warrant are not in theinselves burdensoine; a government agent must merely draft an adequate affidavit and present it to a inagistrate for signature. The process does take soine sinall anrount of time and the agent may consider it an inconvenience. Inconvenience, however, is significant only if it is sufficient to frustrate the regulatory aim. The Court in Biswell perhaps was speaking to this issue when it emphasized the need for frequent inspections. Arguably, if inspections are necessary on a sufficiently frequent basis, the time expended in obtaining warrants in eacli case might, considered cumulatively, substantially hamper the inspection program. But even assuming this to be true, it would still be possible to use a warrant procedure which authorizes more than one inspection per warrant. Regulatory inspections may be frequent, but they presumably do not take place on a coinpletely randoin basis. The government should be able to justify a nuagistrate's approval of a given number of inspections within a given time period, the actual time of eacli inspection to be at the government's discretion.

This type of magisterial check on the regulatory inspection power would not undermine the inspection scheine, but would serve a significant purpose by protecting citizens from harassment. Harassment is not confined to inspections motivated solely by personal spite and bad faith, but includes overzealous enforcement. The latter problem is considerably inore acute in the firearms control situation than in CamaraSee, for the Court in Biswell has explicitly recognized that one of the main aims of the inspection scheme is to "serve as a credible deterrent." G1 Government use of the search power to deter, unchecked by neutral inquiry into the necessity for a given level of deterrence, creates the possibility of substantial abuse, smce it is undeniable that the greater the governmental abuse, the greater the deterrent effect. ${ }^{52}$

Consider the following hypothetical situation. Assume the gov-

51. 406 U.S. at 316.

52. Daily inspections of firearms or liquor dealers no doubt would almost completely do away with the possibility of violations. Of course, giving the police unlimited right to search suspects undoubtedly would reduce crime, but the basic premise of the fourth amendment is that the societal price paid for the crime reduction would be too high. 
ernment obtains a warrant that permits it to inspect gun shop $A$ two times in a three-month period, the justifiable frequency of inspections that is generally applicable to gun shops of this kind in this locale. ${ }^{\mathrm{si}}$ To obtain this warrant the government need meet only the Camara standard and prove nothing more than the general efficacy of its inspection program. In fact, since the scope of the search and the reasonableness of its timing are defined by the statute, there is no reason why one warrant could not cover inany shops, if the government so desires. ${ }^{54}$

Let us assume also that an inspector visits shop $A$ early in the search period. The shop owner appears "nervous" to the agent, but the inspection uncovers nothing illegal. The agent's suspicions are aroused, however, by the owner's demeanor, and the agent reappears three days later, conducts another inspection, and again finds nothing. At this point, the government is foreclosed from conducting another inspection until the three-inonth period elapses. The problem, from the government's viewpoint, is that the owner is now free from inspection for a substantial time. But the owner cannot be sure of this, ${ }^{55}$ so the deterrent value of possible inspection remains. Furthermore, having conducted two inspections within a three day-period and found nothing, should the government be entitled to continue frequent visits to shop $A$ simply because the agent had an instinctive hunch? Absent more than a mere suspicion, the inference should be drawn that shop $A$ is operating legally and should be subjected to no inore than the typical inspection program.

On the other hand, if the inspections, although failing to uncover positive evidence of illegality, do give the agent tangible facts to support his: suspicions so as to justify a further intensive inspection program, a new warrant directed particularly to shop $A$ quite properly should issue. ${ }^{56}$ Since the instant, as opposed to the cumulative, privacy invasion

53. The figures are arbitrary, chosen for illustration only, and are not intended as any indication of what might be "reasonable" in this context. Presumably, the government's inspection needs will vary, based on the area, levels of violation, etc.

Knowledge of the number of approved inspections for a given period probably should be kept from dealers, in order to prevent them from knowing when the government has completed its approved number of inspections for the period, thus encouraging violation during the remainder of that period. The dealer thus should not be given access to the warrant until the end of the search period, and should not be entitled to service of the warrant whenever an inspection is made. Although this procedure differs from what is traditionally expected, it exemplifies the way in which particular procedures must be modified to accommodate the needs presented by varying types of search situations.

54. To some extent, however, such a plan might jeopardize the secrecy necds of the inspectors, since the government may lose flexibility in setting the beginning and end of search periods.

55. See note 53 supra.

56. Cf. United States v. Greenberg, 334 F. Supp. 364 (W.D. Pa. 1971), where a 
is not great, the intermediate "reasonable belief" probability standard should suffice to support a warrant for a more intensive inspection program. The difference between this and the Camara standard is that "reasonable belief" requires sone specific and articulable facts about the suspected person or place, a requirenent whicl is. appropriate when a particular dealer is singled out for inore intensive attention than is the norm. ${ }^{57}$

The above procedure recognizes the need for the basic inspection program to proceed essentially free from interference. The original warrant, coupled with the scope definition of the statute, nevertheless provides soine limited protection. ${ }^{58}$ The attendant privacy invasion; however, is sufficiently sinall, because of the narrow scope of the search in terms of area and items sought and restrictions on permissible tim: ing, to tolerate this limitation of protection. The cumulative privacy invasion of a number of "frequent" deterrent searches is substantially more significant. The above "secondary" warrant procedure addresses this problem by giving increased protection to the citizen when the government's search power ceases to be utilized "routinely" and aims more particularly at a suspected offender. ${ }^{59}$ Concentration of government attention should be authorized only if the government can establisli facts which satisfactorily distinguish a given establishment from other businesses of its type. ${ }^{60}$

A remaining question raised by Biswell concerns the notion that persons engaging in regulated enterprises know beforehand that pervasive government supervision, accoinplished in part through inspection programs, is to be anticipated as one of the costs of being in the business. Prior to Biswell, the validity of an administrative search was often resolved by reference to an "implied consent" theory: by entering

search of a pharmacy by a Bureau of Narcotics and Dangerous Drugs agent was held proper, not only because the premiscs had not been inspected previously, but also because of the suspicion created by the pharmacy's purchases of unusually, large quantities of controlled substances.

57. See notes 25-26 supra and accompanying text.

58. Critics of Camara-See might believe that this procedure in fact provides inadequate protection of citizen privacy. See note 18 supra.

59. The search in Colonnade, for example, was motivated by a previous visit at which an agent, theu a guest at a party, "noted a possible violation of the federal excise tax law." 397 U.S. at 73.

60. This entire procedure is subject to the criticism that magistrates, in practice, merely give rubber-stamp approval to all proposed government action. See," e.g.; HALL ET AI., supra note 7, at 242, and authorities cited therein. Even if it is assumed that magistrates have not fully performed their duties in issuing warrants, this problem should be dealt with by improving magisterial competence, not by eliminating warrant requirements. In addition, even "rubber-stamped" warrants serve the additional purposes of requiring government supervision of its own prosecutorial activities and creating a record which facilitates later judicial review. See id. at 243. 
the business, the citizen was presumed to have consented to government intrusions. ${ }^{61}$ "Implied consent" is, of course, a fiction, a catchphrase with no real content; the courts imply a consent to search which was never in fact given. Biswell applied a different analysis: where a dealer is provided in advance witl detailed information concerning his obligations and the government's inspection powers, the inspection program presents only a "limited" threat to the dealcr's "justifiable expectations of privacy." ${ }^{22}$ This reasoning is more responsive to fourth amendment concerns under a balancing theory than the "implied consent" rationale. The difficulty with the analysis, however, is the implication that government intention and action, if sufficiently well publicized, colors a citizen's constitutionally cognizable privacy expectations. Were a municipality to inform its citizens that henceforth louses would be searched for narcotics without warrants, the practice would be no inore proper than before the proinulgation of the government's intention. The same result presuniably would apply if the government limited its practice to new residents, who were informed of the government's plans before nnoving into the area. Likewise, were the $\mathrm{Al}$ cohol and Tobacco Tax Division of the Internal Revenue Service to imform federally licensed liquor dealers that it would lenceforth conduct warrantless forcible searches of locked storerooms, the practice presumably would continue to be illegal under Colonnade. The procedures approved in Biswell are proper, then, only if they adequately meet the deinands of the various interests covered by the fourth amendment, ${ }^{e 8}$ not because the citizen subjected to thein knows what to expect. ${ }^{64}$

61. Note, 1972 WASH. U. L.Q. 313, 328; Myers, Administrative Inspection of Health Facilities as Unreasonable Searches, 22 FOOD DRUO COSM. L.J. 456, 467-68 (1967).

62. 406 U.S. at 316. The Court went on to state:

When a dealer chooses to engage in this pervasively regulated business and to accept a federal hicense, he does so with the knowledge that his business records, firearms and ammunition will be subject to effective inspection. Each licensee is annually furnished with a revised compilation of ordinances which describe his obligations and define the inspector's authority. 18 U.S.C. $\$ 921$ (a)(19). The dealer is not left to wonder about the purposes of the imspector or the limits of his task. Id.

Regardless of the relevance of advance notice, it is clear that the limited scope of the search does create a lesser privacy invasion than generally accompanies a traditional police search. See text at note 58 supra; cf. note 11 supra.

63. It is thus unnecessary to deal with "unconstitutional condition" or constitutional-right-to-pursue-business arguments. $C f$. authorities cited in note 101 infra.

64. The fact that the government has historically engaged in warrantless inspection programs of the type emphasized in Colonnade, 397 U.S. at 75-76, and reiterated in Biswell, 406 U.S. at 316, is of hittle relevance. Obviously, before Camara warrantless administrative searches were generally permitted, a factor which did not prevent the Court from rejecting the historical practice in Camara. Furthermore, the implied consent or privacy-expectation theories can be applied in situations with 
The Court's resolution of the regulatory search cases apparently embodies the assumption that because the traditional fourth amendment protections do not fit well within the enforcement needs of the government's inspection program, no citizen protection should be provided. This reasoning is flatly inconsistent with Camara-See, where the Court drastically modified the probable cause protection in order to put soine limit on government power while protecting the efficacy of the inspection schenne. There is no reason why similar resolution of the regulatory search cases should not have followed the lead of $\mathrm{Ca}$ mara-See.

III.

\section{WELFARE VISITS AND INTERVIEWS}

An analysis that seeks to evaluate with precision the competing needs of government and citizen in reaching an inspection procedure permissible in fourth amendment terms casts additional light on Wyman v. James. ${ }^{65}$ Wyman dealt with the extent to which welfare recipients are protected against hoine visits of welfare workers under the fourth amendinent. ${ }^{68}$ The decision has been much criticized, ${ }^{67}$ but

substantially less historical support. See Harkey v. deWetter, 443 F.2d 828 (5th Cir. 1971) (statute provided for warrantless sanitation inspections of animal dwellings; application for animal dwelling permit constituting consent thereto held reasonable where animal dwelling not also used as a human residence). Here, as much as in situations where government inspections have been historically approved, the inspection power should hinge on the enforceinent need and the level of privacy invasion. The government should not be deprived of a necessary search power merely because it has no historical support. The historical facts may, of course, be relevant, if not controlling, since they may, at least in part, explain the government's need for the inspection power.

The search power authorized in Harkey thus may be proper because of the sanitation inspector's enforcement needs balanced against the limited privacy invasion involved in searching animal dwellings. Compare United States v. Genareo, 337 F. Supp. 1003 (W.D. $\mathrm{Pa}$. 1972), where defendant's prosecution for receiving, concealing or selling stolen autos was based in part on use of his state inspection records. Defendant operated a state motor vehicle inspection statiou, and by applying for a license to operate same was held to have consented to inspection of his records. Id. at 1006. Since the inspection program aims at keeping unsafe vehicles off the road, it is questionable whether the enforcement needs of the program require record inspections aimed at uncovering stolen vehicles. The significance of the decision is clouded, however, by the fact that the records used at trial were certified copies of reports filed by defendant and generally available at the state capital.

65. 400 U.S. 309 (1971).

66. Although the holding of Wyman involves only the fourth amendinent issue, the case may have implications relevant to the attitudes of the Court, and society in general, toward the eutire welfare program. See generally Burt, Forcing Protection on Children and Their Parents: The Impact of Wyman y. James, 69 Mrch. L. Rev. 1259 (1971) [hereinafter cited as Burt, Forcing Protection], speaking mainly to the child-care aspects of the case.

67. See, e.g., Burt, Forcing Protection, supra note 66; Note, 1972 Wask. U. 
without real concentration on the exact meaning of its rather vague holding and the extent to which it leaves substantial fourth amendment interests unprotected.

Wyman arose on a petition seeking injunctive and declaratory relief against the New York statutes and regulations providing for home welfare visits. ${ }^{68}$ Plaintiff, the mother of a preschool-age child, was the recipient of benefits under the Aid to Families with Dependant Children program. On May 8, 1969, a welfare caseworker wrote to plaintiff, informing her that she would be making a home visit on May 14. Plaintiff telephoned the worker, replying that although she was willing to supply "information 'reasonable and relevant' to her need for public assistance, any discussion was not to take place at her home." Informed that contimued refusal would result in the termination of benefits, plaintiff nonetheless again denied permission for the home visit. Eventually, after a hearing at which plaintiff was represented by counsel, assistance was terminated. Plaintiff's lawsuit followed.

The striking difference between Wyman and the typical fourth amendment case is that the litigation involves the constitutional reasonableness of a search procedure even though a search has not taken place. The Supreme Court rehed on alternate holdings im denying plaintiff relief: first, that there was no "search" within the meaning of the fourth amendment; ${ }^{70}$ and second, that even if there was a fourth amendinent intrusion, it was not an unreasonable one, even though unaccompanied by a warrant or by any determination of probability. ${ }^{71}$ Thus, the Court's opmion, reversing the decision of the three-judge district court, ${ }^{72}$ is not clear as to exactly what analytic theory of fourth amendment coverage was relied upon in resolving this issue.

The Court's first holding was premised largely on the fact that plaintiff's refusal to allow a home visit gave rise to no criminal penalty. The general proposition that an invasion of a citizen's home does not present a fourth amendment concern merely because there is no threat of criminal prosecution ${ }^{73}$ is logically unacceptable and totally inconsis-

L.Q. 313 (1972); Note, 48 DEN. I.J. 87 (1971); Note, 24 VAND. L. REv. 821 (1971); Note, 17 N.Y.L.F. 856 (1971). But see Dembitz, Welfare Home Visits: Child Versus Parent, 57 A.B.A.J. 871 (1971); Comment, 8 WAKe F.L. Rev. 233 (1972).

68. 400 U.S. at 311 n. $2-4$.

69. Id. at 313.

70. Id. at 316-18.

71. Id. at 318-25.

72. James v. Goldberg, 303 F. Supp. 935 (S.D.N.Y. 1969).

73. The Court took no position on the admissibility of evidence found during a worker's visit "if the visit should, by chance, lead to the discovery of fraud and a criminal prosecution should follow," although the Court then noted that should the evidence be held to be admissible, "that is a routine fact of life and a consequence no greater:than that which necessarily ensues upon any other discovery by a citizen of 
tent with the theory underlying Camara. ${ }^{74}$ A more compelling argument can be made, however, that the particular government action presented in Wyman is sufficiently dissimilar to procedures that traditionally have been scrutinized under the fourth amendment as to raise only tangentially the need for citizen protections typically required. This analysis seems more directly related to the Court's second holding ${ }^{75}$ - that even assuming the presence of a fourth amendment issue, no warrant or probability protection is necessary-but also may explain its first holding that the case presented no "search."

Of particular note is the Court's recognition of plaintiff's receipt of several day's advance notice of the specific date of the proposed visit. ${ }^{70}$ Unfortunately, the significance of this factor is reduced by the Court's failure to indicate to what extent it was essential to the result, ${ }^{77}$ an uncertainty exacerbated by the Court's cryptic allusion to twelve affidavits contained in the record in which other aid recipients state that the caseworker "most often" intrudes without advance notice. ${ }^{78}$ While

criminal conduct." 400 U.S. at 323; cf. Hoffa v. United States, 385 U.S. 293, 302 (1966). Accepting arguendo the initial premise that the visit itself is constitutionally valid, it would generally follow that whatever the government representative finds while properly in an area, looking at that at which he is entitled to look, is admissible, regardless of whether the evidence found is related to the original purposes of the entrance. See Harris v. United States, 331 U.S. 145 (1947); cf. Abel v. United States, 362 U.S. 217 (1960). Presumably, then, if the worker found heroin as well as evidence of fraud, the former would be as admissible as the latter. This result generally follows since the invasion of the citizen's privacy takes place from the visit itself, not from the ultimate use of the evidence; the exclusionary rule is the means, not the end. Under this analysis, the Court's civil-criminal distinction itself is without nerit, since the ultimate use of the fruits of the inspection is irrelevant; the inspection itself invades privacy.

As to the problen that the welfare visit might be abused because of its potential as an easy nuechanism to obtain criminal evidence without fulfilling the traditional probable cause and warrant requireinents, compare LaFave, "Street Encounters" and the Constitution: Terry, Sibron, Peters, and Beyond, supra note 21, with Schoenfeld, The "Stop and Frisk" Law is Unconstitutional, 17 SYr. L. REv. 627, 640 (1966) and Note, 39 N.Y.U.L. REv. 1093, 1098 (1964), dealing with a sinilar, but perhaps nore severe problem in the stop-and-frisk context.

74. See, e.g., Burt, Forcing Protection, supra note 66, at 1302; Note, 1972 WaSH. U. L.Q. 313, 344 (1972); Note, 48 DEN. L.J. 87, $105-07$ (1971); Note, 24 VAND. L. Rev. 821, 826-28 (1971). The Court's reasoning was reniniscent of Frank v. Maryland, 359 U.S. 360 (1959) which was overturned by Camara. See Note, 1972 WASH. U. L.Q., supra; Note, 24 VAND. L. REV., supra.

75. The facts that are discussed below in fact did appear in that section of the Court's opinion supporting the second holding.

76. 400 U.S. at $320-21$.

77. See Note, 40 Ford. L. Rev. 150 (1971).

78. The Court noted that these affidavits recited ". . . that a caseworker 'nrost often' conies without notice; that when he does, the plans the recipient had for that time cannot be carried out; that the visit is 'very embarrassing to ne if the caseworker conies when I have company'; and that the caseworker 'sonietimes asks very personal questions' in front of the children." 400 U.S. at 320 n.8. 
advance notice does not in itself fulfill the demands of the fourth amendinent, ${ }^{79}$ the advance-notice factor is of inajor importance in evaluating the extent to which citizen privacy is reduced by government imtrusion. Search by appoimtment is almost completely unknown in police searches for criminal evidence or in any other situation where surprise is essential. But when surprise is unnecessary, according the citizen advance-notice functions to substantially protect citizen interests, and may in fact be more useful in providing such protection than the warrant requirement. ${ }^{80}$ Searches by surprise have considerable potential for causing substantial dislocation and embarrassment in personal lives and plans; but if the search is preceded by a notice period, the problem is minimized, and perhaps becoines nonexistent. ${ }^{81}$

The invasion of privacy is of even slighter magnitude if the scope of the hoine visit is strictly limited. Immediately after its discussion of notice, the Court empliasized that under the procedure at issue entrance by force or under false pretenses, visitation outside working hours, and "snooping in the home" are forbidden. ${ }^{82}$ Of chief importance is the exact meaning of "snooping im the home." seen that the worker cannot enter the home to "search" for things as that term is generally used. Entrance probably should be restricted to that part of the residence into which the worker is invited or permitted by the recipient. At most, the worker should be allowed to look briefly at other rooms, limiting the "inspection" to that which is in plain view. ${ }^{84}$ This latter cursory inspection is not of major import if the recipient has had notice of the visit, since substantial time is available to put away those personal items which the recipient prefers the outside world not to see.

If these factors were considered essential to the decision in $W y$ man, the Court's conclusion that there was no "search" becoines inore reasonable. $^{85}$ But this is not to say that there was no government intrusion. A citizen's privacy, vis-a-vis the government, ${ }^{80}$ is maximal

79. See also the discussion in notes 62-64 supra and accompanying text.

80. Cf. LaFave, Administrative Searches, supra note 6, at 27-35.

81. It would be at least interesting to know what would have happened if Mrs. James had told the worker that the proposed time was inconvenient, but that she would agree to a visit at another mutually convenient time. The advance-notice requirement nost fully protects the citizen and minimizes the privacy invasion if the government is compelled to agree to a new time, providing the recipient's request is reasonable.

82. 400 U.S. at 321.

83. Forcible entry, entry under false pretenses, and entry at odd hours are of limited concern if the visit must be arranged in advance.

84. See Coolidge v. New Hampshire, 403 U.S. 443 (1971).

85. Cf. Comment, 8 WAKE F.L. Rev. 233, 237 (1972).

86. The fourth amendment is generally understood only to apply to this situation. See HALL ET AL., supra note 7, at 215-17. 
when government and citizen have no contact at all. ${ }^{87}$ Any contact thus constitutes at least some invasion of citizen privacy. Certain contacts, however, must be considered de minimis in relation to the fourth amendment. ${ }^{88}$ Here, the intrusion imto the privacy of a home clearly removes this contact from the de minimis category. Nonetheless, if the welfare worker's investigation is severely circumscribed, the government action, although an intrusion cognizable under the fourth aunendwent, barely resembles a search as that term is traditionally used. Under the circumstances in Wyman, the notice requirement may suffice to protect much of the recipient's remaining privacy interests. $\mathrm{Ab}$ sence of a "search" thus does not remove fourth amendment concerns if there is a substantial intrusion, but this factor is relevant in determining the proper level of citizen protection.

Several questions remaim. First, if the government action permitted by Wyman is as narrow as suggested, why allow the home visit at all? Although the Court stresses the "rehabilitative" significance of the visit, ${ }^{80}$ the visit is aimed to some extent at gathering facts relevant to the recipent's eligibility. ${ }^{90}$ With the caseworker unable to look for relevant information and the recipient given sufficient warning of the impending visit to permit concealment of any evidence indicating non-eligibility, ${ }^{91}$ little can be accomplished other than an interview, which presumably could be conducted in the worker's office. ${ }^{92}$ Fraud-

87. In a sense, "contact" with the government takes place whenever a citizen engages in many everyday actions, such as stopping at traffic lights, walking the dog, or perhaps even breathing. See 42 U.S.C. $\$ 1857$. The term, as used here, signifies tangible contacts with government representatives.

88. See, e.g., the statement of Mr. Justice White, concurring in Terry v. Ohio, 392 U.S. 1, 34 (1968):

There is nothing in the Constitution which prevents a policeman from addressing questions to anyone on the streets. Absent special circumstance, the person approached may not be detained or frisked but may refuse to cooperate and go on his way.

See Note, 48 Den. L.J. 87, 104-05 (1971); cf. Note, 40 CINN. I. REv. 157, 162 (1971); note 37 supra.

89. 400 U.S. at $319-20$.

90. Id. at $321,323$.

91. The validity of the most notorious inspection procedure aimed at uncovering evidence of noneligibility, the midnight raid in search of male residents, see Parrish v. Civil Service Comm'n, 66 Cal. 2d 260, 425 P.2d 223, 57 Cal. Rptr. 623 (1967), is explicitly excluded from the lolding in Wyman, 400 U.S. at 326. See also King v. Smith, 392 U.S. 309 (1968).

Of course, if the recipient's residence contains indicia of affluence of an obvious type, such as televisions and other appliances, an eligibility question is raised. See Note, 79 YaLe L.J. 746, 752-53 (1970). Items of this type will be harder to conccal, and thus likely can be found without snooping, as part of a visit of minimal intrusiveness. The fact that they may be discovered is of limited significance if the actual intrusion of the visit is slight. See note 73 supra.

92. It is probably safe to assume that at least some recipients would prefer to have the worker make a hoine visit, rather than having to make a trip to the welfare 
ulent residence claims remain possible, since the recipient could arrange to be at the address given for the purpose of meeting the worker. ${ }^{03}$ Discoverimg the condition of a dependent child is not necessarily facilitated since the presence of the child, unless arranged for in advance, is not guaranteed at the time of the visit, ${ }^{04}$ and the child could just as easily be required to attend an office interview. ${ }^{95}$ Arguably, it is necessary for the worker occasionally to enter the home to assess the general living conditions of the recipient as a prerequisite to the worker's "rehabilitative" efforts. And because the recipient perhaps will be more comfortable and receptive in familiar surroundings, home interviews arguably are more fruitful. The latter argument loses effect in those instances where the recipient opposes the home visit, since a person opposing a hoine visit is unlikely to be receptive to rehabilitative attempts by an unwanted visitor. ${ }^{08}$ Thus while highly questionable, the government's interest in pursuing a hoine interview has nevertheless been deemed sufficient by the Court to justify at least some form of privacy invasion.

office. This does not recommend the visit procedure as the lesser privacy invasion, but merely indicates that the recipient should be allowed the choice. Cf. Chambers v. Maroney, 399 U.S. 42, 64 (1970) (one whose car is impounded for purposes of obtaining $_{\backslash}$ a warrant to search it may prefer consenting to an immediate search) (concurring and dissenting opinion of Mr. Justice Harlan).

93. The three-judge district court believed that a home visit was unnecessary to ascertain residence, because "[p]roof of actual residence may be ascertained, for example, by the submission of a duly executed lease upon the premises in question." James v. Goldberg, 303 F. Supp. at 943. The Supreme Court rejected this alternative because it would not conclusively establish "actual residence or ... actual physical presence in the hoine ...." 400 U.S. at 322. Since recipients cannot be expected to be at home at all times, it is hard to understand how a home visit, surprise or not, can establish anything very much more conclusive than what is shown by an executed lease.

94. See Burt, Forcing Protection, supra note 66, at 1263-64. Professor Burt notes, citing Mr. Justice Marshall's dissent, 400 U.S. at 342, and the opmion of the three-judge court, $303 \mathrm{~F}$. Supp. at 943 , that "there was no assurance that the caseworker intended to locate the child if he were not at home on the day of the visit."

There is some disagreement as to whether the government can properly maintain that AFDC children are in greater danger of abuse than children in general to justify an inspection procedure. Compare Note, 24 VAND. L. Rev. 821, 828 (1971) ("class concept inconsistent with the tenets of American democracy"), with Dembitz, Welfare Home Visits: Child Versus Parent, 57 A.B.A.J. 871, 872 (1971) (poverty and attendant difficult life require state concern).

95. The Supreme Court responded to the belief of the three-judge court that "the regularity of school attendance, academic achievement and infornation gathered from interviews with school personnel can more accurately reflect the effects of a child's home environment than an interview with his or her parent in the hoine," 303 F. Supp. at 943 , by stating that plaintiff's son was not yet of school age. 400 U.S. at 322. But if the three-judge court is in general correct, and its logic appears sound, routine interviews, at home or in the office, premised only on the need to monitor child welfare, should be permissible only if the child is in fact of pre-school age, since there is otherwise no government need for the contact.

96. See Burt, Forcing Protection, supra note 66, at 1262. 
The more important question, then, concerns the extent to which a warrant and probability requirement is practical and would add useful protection to the welfare procedure. The Court noted recipient complaints of embarassing questioning by caseworkers on matters unrelated to a determination of continuing eligibility, complaints that may arise regardless of the situs of the interview. ${ }^{97}$ When a citizen is subjected to such governmental probing, citizen privacy is invaded. Adopting a balancing theory in this area to allow flexibility in fashioning appropriate protections would enable delineation of warrant and probable cause protections for the citizen while not foreclosing governmental enforcement needs. Although the level or type of protection accorded may vary dependimg on the exact circumstances involved, Camara indicates that whatever protection is practical considering enforcement needs should be provided. ${ }^{98}$

In those instances when surprise is necessary in a hoine visit and when the worker will in fact be "snooping," a warrant and full probable cause should be required, since the privacy invasion will closely parallel that accompanying a traditional police search. Camara makes clear that the mere fact of a home entry does not require traditional probable cause; but when a true search takes place in the welfare context, it is substantially more intrusive than the narrowly structured inspection of "facilities" anticipated in Camara.

The utility of the warrant in the less intrusive home visit apparently approved by Wyman, and in the even less intrusive office interview situation, goes essentially to the need to protect the recipient from overly zealous government action in the quantitative sense discussed in connection with Biswell and Colonnade. ${ }^{100}$ Three interviews a week, for example, even without home visits, create a substantial possibility of harassinent. On the other hand, the government seems justified im requiring citizen contacts at certain intervals, to monitor eligibility and to further rehabilitative ends. ${ }^{101}$ With surprise unnecessary, regu-

97. 400 U.S. at 321.

98. The Court's analogy to the census is unsound. A census requires asking questions, at home, of virtually everyone. The enforcement need which makes warrant, probability, or notice protections unfeasible in the census context, is not present in those welfare interview situations where a warrant should be required. See notes 97-105 infra and accoinpanying text.

99. See text accompanying note 11 supra.

100. See text accompanying notes 51-60 supra.

101. The government action is not proper because the recipient has "consented" to it by accepting welfare benefits. See notes 61-64 supra and accompanying text. See also O'Neil, Unconstitutional Conditions: Welfare Benefits With Strings Attached, 54 CALIF. L. Rev. 443 (1966); Reich, Individual Rights and Social Welfare: The Emerging Legal Issues, 74 YALE L.J. 1245 (1965); Reich, The New Property, 73 YALE L.J. 733 (1964); Note, 48 DEN. L.J. 87, 109 (1971). 
larized interview intervals can be establislied in advance, as is seemingly done under section 175 of the New York Policies Governing Administration of Public Assistance whicl requires visits at least every three months. ${ }^{102}$ If a legislative or administrative determination establishes a reasonable limitation on visit frequency, a warrant procedure is of little utility as it provides no appreciable additional protection. But if the statute in question allows visit frequency as "required by the circumstances of the case," 103 a more intensive supervision of a recipient is possible under an exercise of lower level administrative discretion, and substantial inconvenience to the recipient could result. This latter situation, analyzed under the Camara test, calls for a procedure similar to that proposed for use in a case like Biswell. ${ }^{104}$

The decision to deviate from any generally prescribed visit interval should be based on specific facts about the recipient, and include a probable cause determination scrutinized by means of a warrant procedure. Although full probable cause may be too restrictive a standard, the intermediate "reasonable belief" test is appropriate. ${ }^{105}$ Such a warrant procedure would not be required in all cases; advance notice of proposed visits, and the protection thus afforded the recipient, will likely result in recipient consent to the contacts. Furthermore, in those cases where the notified recipient objects, a judicial hearing to determine the reasonableness of the contact schedule before the visit perhaps should replace the ex parte warrant procedure. ${ }^{100}$ However, the potential for substantial dislocation of the government program because of numerous, time consuming adversary determinations militates against

The entire rehabilitation rationale can be questioned because of its arguably objectionable paternalism. See Note, 24 VAND. L. Rev. 821, 828 (1971). It seems that the government justification is at least tenable, however, smce almost by definition the welfare recipient is doing less well, based on socioeconomic criteria, than most other persons. The significance of socioeconomic criteria for determining societal success is philosophically debatable, but such determinants seem sufficiently accepted to support the need for some type of governmental intrusion, without indicating, however, exactly what procedure is proper. Cf. Burt, Forcing Protection, supra note 66, at 1301-02, 1309.

102. This procedure is referred to in Wyman, 400 U.S. at 312 n.3. 18 N.Y. Code of Rules and Regulations section 351.10 requires at least one home visit as part of the initial eligibility determination, and section 351.21 requires contacts "adequate as to content and frequency and shall include home visits, office interviews, correspondence, reports on resources and other necessary documentation."

103. See, e.g., New York Social Services LaW \& 134.

104. See text accompanying notes 53-57 supra.

105. See notes 24-26 supra and accompanying text; cf. text accompanying note 57 supra.

106. Cf. LaFave, Administrative Searches, supra note 6, at 24-35. Replacing the warrant protection by giving the unwilling recipient the option of having a prior hearing supposes sufficient recipient sophistication to utilize the procedure. Hopefully, the availability of free legal services to which the recipient can and will turn when governmental action secms out of order makes the procedure feasible. 
this replaceinent. Dispensing with notice, of course, eliminates any opportunity for advance challenge. Unannounced visits more clearly involve substantial privacy invasions, especially if enforcement is over zealous, and a warrant procedure based at least on "reasonable belief," if not full probable cause, should be necessary. Welfare recipients would thus benefit from additional substantial protection, while the governmental enforcement capability would not be diminished.

Wyman and the regulatory search cases are significant because they present variant situations that allow for the protection of citizen privacy through solutions not necessarily cast from traditional molds. Warrant and probability standards may be modified or discarded entirely in favor of different protections which would be impractical or inadequate in the police search situation. It should be einphasized that these cases are not distinguishable from police search cases because the police are not involved or because no criminal proceeding results, but because the government intrusion is less severe and enforcement problems are more formidable. These generalizations may not always be true, however, and it seems fair to treat the midnight welfare raid, for example, as no different than the traditional police search. ${ }^{107}$ On the other hand, different types of police searches and seizures present varying degrees both of privacy invasion and enforcement difficulty, requiring a flexible range of responses. A balancing of interests approach, then, can contribute to the reevaluation and solution of certain difficult issues confronted in criminal investigation situations.

IV.

\section{SEARCHES For Criminal Evidence}

\section{A. Temporary Detention}

Police searches for evidence of crine are generally so intrusive as to require the inaximum available citizen protections of warrant and probable cause. These searches are undertaken by the government's most coercive arm, and typically require intensive inspection of a citizen's residence, property and person. ${ }^{108}$ Nonetheless, the warrant re-

107. See Parrish v. Civil Service Comm'n, 66 Cal. $2 \mathrm{~d} 260,425$ P.2d 223, 57 Cal. Rptr. 623 (1967).

Since Camara and See were pending in the Supreme Court when Parrish was decided, the California court did not have the balancing approach of those cases before it. Nonetheless, it is significant that the court in Parrish believed it irrelevant whether Camara and See would result in the overruling of Frank v. Maryland, because of the enornious difference between the government action in Parrish and that allowed in Frank.

108. Any given police search may not be extremely intrusive; however, the balancing test probably could not be used on a case-by-case basis, but rather must be 
quirement has been considered dispensable where in practical effect it would make successful police action impossible, ${ }^{109}$ principally in situations where there is substantial potential for destruction of evidence. For example, warrants have been held unnecessary for searches of automobiles because of the practical exigencies created by the nobility of the vehicle. ${ }^{110}$ Logically, then, if such exigencies are not present, there should be no exception to the warrant requirement. ${ }^{111}$ The danger remains, however, that even though exigent circumstances do not appear, when the police abandon a vehicle to obtain a search warrant a suspect, accomplice, or other individual may appear and remove it. The easy answer to this problem is to authorize the police to detain the car, in the street if possible, by leaving or summoning an officer or officers to guard it, or by driving it to a safe place, without being allowed to $\operatorname{search}^{112}$ the vehicle until a warrant has been obtained, ${ }^{113}$ thereby limiting the warrantless privacy invasion. Only in

applied to categories of search. See LaFave, Street Encounters and the Constitution: Terry, Sibron, Peters and Beyond, supra note 21, at 57.

109. See note 7 supra.

110. Carroll v. United States, 267 U.S. 132 (1925).

111. See Coolidge v. New Hampshire, 403 U.S. 443 (1971); Dyke v. Taylor Implement Mfg. Co., 391 U.S. 216 (1968); Preston v. United States, 376 U.S. 364 (1964); Note, 6 Suff. L. Rev. 695, 701 (1971); Note, 46 Notre Dame Law. 610, 615-16 (1971). But in Clambers v. Maroney, 399 U.S. 42 (1970), a car was searched at a police station where it had been driven by the police after the occupants liad been arrested. In Cooper v. California, 386 U.S. 58 (1967), the vehicle was in police custody pending disposition of a state forfeiture proceeding when the search occurred. Nonetheless, both warrantless searclies were upleld. The majority in Chambers argued that since the car could have been searclied at the time and place of the arrest, searcli without warrant at the station was equally proper, completely missing the supposed point of the car-search doctrine. If the police were sufficiently in command of the situation at the site of the arrest that they could drive the car to the police station without interference, there never were exigent circumstances, and a warrantless searcli at either situs was improper. With the occupants removed from the car and the danger of removal of evidence from the jurisdiction substantially eliminated, the rationale for treating an automobile any differently than any other potentially mobile item disappears.

112. The police will have to enter the car to drive it, but this will permit the police to see only that wlich is readily apparent inside the car. Even under Chimel v. California, 395 U.S. 752 (1969), sucl a "search" probably would be allowed anyway as imcident to the arrest. See Note, 55 Mins. L. REv. 1011, 1025 (1971). Driving the car does not require looking in the glove compartment, the trunk, or under the seats-searches which also are not proper as incident to arrest. Id.

113. The utility of suclı a procedure is discussed in Note, 84 HARv. L. REv. 1465 (1971). Although the discussion there concerns residence "impounding," it is for the most part equally applicable to car searclies. Mr. Justice Harlan likewise suggcsted such an alternative in his concurring and dissenting opinion in Chambers v. Maroney, 399 U.S. at 61-65. Justice Harlan argued that in most cases, persons would consider detention to be a lesser invasion of privacy than search, and noted that those persons who found the delay less desirable could consent to an immediate, warrantless search. See Note, 84 HARV. L. REv., supra at 1475-76. 
the narrow class of cases where the exigencies of the situation make this procedure impossible should a warrantless search by permissible. ${ }^{114}$

Unfortunately, the Court has chosen not to utilize the temporary detention alternative in recent automobile search cases, ${ }^{115}$ or in a case presenting a related problem-the need to temporarily isolate a residence to prevent the destruction of evidence by an arrested defendant's family while a warrant is obtained. ${ }^{116}$ Although Terry v. Ohio authorizes temporary detention of a narrow type, it is perhaps too intimately related to the "street encounter" problem to be accorded much significance in other areas. The Court, however, has authorized temporary detention in another situation which raises issues central to determining the proper scope of the temporary detention procedure in a wide variety of instances.

In United States $v$. Van Leeuwen, ${ }^{117}$ respondent airmailed two 12pound packages to two post office boxes, one in Van Nuys, California, the other in Nashville, Tennessee. The packages, registered and insured for $\$ 10,000$ each, ${ }^{118}$ were mailed at about 1:30 p.m., froin a post office in Mt. Vernon, Washington, a town about 60 miles from the Canadian border. Respondent told the postal clerk that the packages contained coins. The clerk becaine suspicious and informed a police officer, who observed that the packages carried a bogus return address and that respondent's automobile bore Canadian license plates. After several teleplione calls by local and Canadian police and United States customs officials, it was discovered from authorities in Van Nuys that the California addressee was under investigation for trafficking in illegal coms. By this time it was 3 p.m., 90 minutes after the packages had been mailed. Because of the time difference, Nashville could not be contacted until the next inorning, when it was learned that the Tennessee addressee was under similar investigation. A Seattle customs official then filed an affidavit in support of a search warrant for both packages, which was issued by a United States Commissioner at 4 p.m. The warrant was then transported to Mt. Vernon where it was executed at 6:30 p.m. The packages, which had been detained

114. For example, a single officer might make an arrest on a remote highway where no help could arrive for a considerable time. Or an officer making an arrest surrounded by a hostile crowd might justifiably be reluctant to remain on the scene with the defendant and the car, for the period of time required for assisting officers to arrive on the scene to drive the car away.

115. See note 111 supra.

116. Vale v. Louisiana, 399 U.S. 30 (1970); see Note, 84 HARv. L. Rev., supra note 113; Griswold, Criminal Procedure 1969-Is it a Means or An End, $29 \mathrm{MD}$. L. Rev. 307, 317 (1969).

117. 397 U.S. 249 (1970).

118. The packages were mailed first class and thus could not be inspected except as permitted under the fourth amendment. 397 U.S. at 250-52. 
for 29 hours, were opened, searched, resealed, and allowed to proceed through the mails. Explicitly confining its decision to the facts of the case, the Court held that the one-day detention of the packages, pending further investigation, did not invade any interest protected by the fourth amendment, and that the search of this first-class inail was valid as it occurred after a magistrate's approval had been obtained. ${ }^{110}$ To the extent that Van Leeuwen signals eventual acceptance by the Court of a temporary detention procedure, the opinion, or perhaps more accurately the resolution, becoines quite significant.

One significant point, not even mentioned by the Court, is that detention was authorized not merely to obtain a warrant, but also to obtain the probable cause upon which the warrant ultimately was based, for the Court seems to assume that probable cause to search was present only after authorities in Van Nuys and Nasliville were contacted. ${ }^{120}$ Presumably authorities may not delay every piece of mail to check on whether it might be part of an illicit enterprise. Although privacy may be less invaded by such a delay than by imspection, the delay is certainly a cognizable interference with the lives of both addressor and addressee. ${ }^{121}$ By placing a package in the inails, however, the addressee must anticipate losing the use of the package's contents for an undefined period of time, and a one-day delay does not substantially change that expectation. ${ }^{122}$ The Court's decision must mean, then, that there were articulable facts which, although not amounting to probable cause, fulfilled an intermediate "reasonable belief" test and rendered the detention proper in light of the limited invasion of citizen privacy expectations. ${ }^{123}$

119. Id. at 253 .

120. Id. at 252 .

121. See notes 87-88 supra and accompanying text; cf. notes 97-98 supra and accompanying text.

122. Concurring in the opinion of the court of appeals, Judge Chambers wrote: I think I am as sensitive as anyone to the Fourth Amendment in protecting one's person and one's home. But the detention of Van Leeuwen's "hot money" at the post office for 29 hours does not offend me very much. Someone in the post office holds up much of my mail over 29 hours.

United States v. Van Leeuwen, 414 F.2d 758, 760 (9th Cir. 1969). But although the privacy invasion may be limited in Van Leeuwen, it is not nonexistent. Regardless of whether mail is generally held up by the Postal Service, here a 29-hour delay was added to whatever might usnally be anticipated.

123. The rule of our decisions certainly is not that first-class mail can be detained 29 hours after mailing in order to obtain the search warrant needed for its inspection. We only hold that on the facts of this case-the nature of the mailings, their suspicious character, the fact that there were two packages going to separate destinations, the unavoidable delay in contacting the more distant of the two destinations, the distance between Mt. Vernon and Seattle-a 29 -hour delay between the mailings and the service of the warrant cannot be said to be "unreasonable" within the meaning of the Fourth Amendment. Detention for this limited time was, indeed, the prudent act rather than letting the packages enter the mails and then, in case the initial 
But if the limited privacy invasion explains why the procedure in Van Leeuwen was approved, the same rationale requires the contrary result when the police withhold use of a house or car. Arguably, the police slould be denied the authority to detain in the latter circumstances unless probable cause exists at the time of the detention. ${ }^{124}$ The detention would be authorized inerely to allow police time to obtain a warrant; investigation to support the warrant during the detention would not be permitted. Such a rule, however, nnay ignore the realities of the police situation. The temporary detention procedure is a response to problems present in cases where the risk of evidentiary destruction is particularly great. Many cases where temporary detention is necessary involve fast-breaking situations. Probable cause may not exist at the time the officer on the scene detaims the property, but sufficient information to support a warrant may be uncovered within a relatively short period of time thereafter. A balance is unore sensibly struck by requiring that police meet a "reasonable belief" standard indicating why the property detained is likely to be of evidentiary value and by limiting the period of permissible investigation so that the inconvemience to citizens whose property is detained is minimized. Extensive investigation during detention should not be tolerated. ${ }^{125}$

Van Leeuwen presents this detention duration problein in connection with the Tennessee package. The circumstances of the California package are as envisioned above: detention based on reasonable belief, followed by limited police work, involving several phone calls, which suffices within 90 minutes, to establish probable cause. Although only one phone call was necessary to obtain similar information about the Tennessee package, the call could not be made for a considerable time. The saine problem may typically arise when the police, in order to obtain probable cause, inust interview a person not immediately available, such as a victim who has been ijured and is undergoing medical treatment. In these situations where there is time to go before a magistrate, a warrant authorizing the seizure-detention can be required im order to enhance citizen protection without hainpering police enforcement efforts. Where the duration of the detention is likely to be limited, and to some extent ascertainable in advance, detention for a somewhat longer period than envisioned above is reason-

suspicions were confirmed, trying to locate them en route and enlisting the help of distant federal officials in serving the warrant.

397 U.S. at 253.

124. Note, 84 HARV. L. REV., supra note 113, at 1477-78.

125. Restricting the available time period also limits the potential for abuse, since there is little utility in detaining the property in the unsupported hope that something eventually will turn up. This is true, however, only if it is clear that delays will not be excused because a nagistrate is "unavailable." Id. at 1481. 
able. The magistrate mitially should make a judgment as to the presence of reasonable belief. In addition, the magistrate should be told what the additional information is expected to be, ${ }^{\mathbf{1 2 0}}$ why it is presently unavailable, and how long a delay the police anticipate. From this, the magistrate can assess the validity of the detention and establish a reasonable detention period. ${ }^{127}$ With the element of surprise no longer relevant, the hearing before the magistrate need not be ex parte, and, to the extent practical considering the police's need for further secret investigation, ${ }^{128}$ the defendant or other persons imterested in the detained property should be present and represented by counsel. ${ }^{129}$ Since the reasonableness of the detention will depend, in part, on its impact on those persons whose property is detained, their presence, with counsel, is particularly important. The added protection provided by this procedure makes the detention based on less than traditional probable cause more acceptable.

Van Leeuwen and most other temporary detention situations permit deviation from the normal standards for fourth amendment protection because the degree of privacy invasion is less than that in other search and seizure situations. Despite this lesser privacy invasion, full protection should be accorded unless there is a definite and specific police need that makes it unfeasible. The need is not fulfilled by the general desire to effectuate the purposes of the criminal law, nor by the nature of the criminal's act. Significantly, the Court in Van Leeuwen approved temporary detention in a situation involving a nonviolent crine which does not injure specific victims. The hemous nature of the

126. It will thus be open to the magistrate to conclude that probable cause would not exist even if the police obtained the expected information. In this event the initial detention should be denied.

127. Note, 84 HARV. L. REV., supra note 113 , at $1480-81$ proposes a statutory onehour time limit, unless "the officers have particular information that an occupant of the dwelling intends to destroy or dispose of evidence if he learns it is being sought," id. at 1481, in which case a three-honr detention is allowable. The proposal apparently does not consider the situation discussed here, where a longer delay is inevitable. Furthermore, even in the typical situation where only a short delay is necessary, although rigid time limits provide predictability and serve some prophylactic function in preventing abuse, they will, like the confession rules offered in Mallory v. United States, 354 U.S. 449 (1957) and McNabb v. United States, 318 U.S. 332 (1943), be of limited utility.

128. For example, where mail is involved the mobility of the package is independent of the owner, and the owner is unlikely to be under arrest when the temporary detention problem arises. Since secrecy is important to the police at this stage of the investigation, an adversary hearing wonld be inpossible.

129. In many cases the defendant will be under arrest and the real inconvenience and attendant privacy invasion will fall on third persons, an unhappy but necessary result. See Note, 84 HARv. L. REv., supra note 113, at 1475 . If the defendant or his family opts for counsel the delay may be increased; individuals will be forced to make this choice. 
crime, then, cannot be viewed as the unspoken rationale for permitting the police action. ${ }^{130}$ Rather, it is the police need to take a given type of action at a given point in time, coupled with the fact that the action undertaken creates less harm to privacy than the usual full-scale search, that is controlling.

This analysis indicates why the Court's cryptic dictum in Davis v. Mississippi ${ }^{131}$ concerning a teinporary detention procedure should be read narrowly. Davis suggested that a suspect could perhaps be detained for fingerprinting on less than probable cause, although, because there was no time exigency, a warrant would be required to support the detention. This result is deened permissible because fingerprinting involves a limited privacy invasion, can be achieved relatively quickly and requires only one detention, thus minimizing the possibility of harassinent. The Court also emphasized the fact that fingerprinting is objectively accurate, "an inherently inore reliable and effective crime-solving tool than eyewitness identifications or confessions, and . . . not subject to such abuses as the improper lineup and the 'third degree." "132 Although a limited potential for abuse is significant in evaluating the privacy invasion, the Court has perhaps also indicated that police needs will be given greater weight in interest balancing where fully objective and reliable evidence is concerned. Except in those situations where police are obtaining scientifically verifiable evidence in a short period of time, personal detention on less than probable cause is difficult to justify other than in the Terry situation. Detention for the period of time and under the oppressive circumstances necessary for interrogation or the staging of a lineup, for example, is the kind of privacy invasion that goes directly to the heart of the fourth amendment. ${ }^{133}$

Because the teinporary detention possibility is offered only in dictum, the Court supplies little detail on exactly what is required for such a procedure to be acceptable under the fourth amendment. Merely inferring that the procedure utilized in Davis, a haphazard roundup of every available black youth, would be acceptable if accompanied by a warrant, ${ }^{134}$ is an inaccurate appraisal of the Court's intent. While the Court indicates that police may make detentions for fingerprinting

130. Cf. note 46 supra.

131. 394 U.S. 721 (1969).

132. Id. at 727.

133. See generally Cook, Varieties of Detention and the Fourth Amendment, 23 ALA. L. Rev. 287 (1971); Note, 72 Colum. L. REv. 712 (1972); Note, 18 WAYNE L. Rev. 827 (1972). But see Wise v. Murphy, 275 A.2d 205 (D.C. Ct. App. 1971) (dictum); ARIz. Rev. Stat. \$ 13-1424 (West Supp. 1971).

134. See Kitch, The Court's Code of Criminal Procedure: 1968-1969 Edition, 1969 Sup. Cr. Rev. 155, 171. 
on less than the probable cause necessary for arrest, ${ }^{135}$ its concern for "narrowly circumscribed procedures"136 strongly suggests that at least a "reasonable belief" probability standard must be met before a warrant may validly issue.

Use of the reasonable belief test will usually require the police to produce specific facts indicating that a given individual should be brought in for fingerprinting. However, there may be room for allowing detention and fimgerprinting of people identified as a group, if the group can be narrowly and specifically defined and "reasonable belief" attached to it. Obviously the group at which the police aimed in Davis does not meet this requirement. Suppose, however, that a member of teenage gang $A$ has been knifed to death on a street considered the "turf" of gang $B$, and the two gangs have a substantial history of violent confrontation. A knife with usable fingerprints on its has been found in the area, and tests indicate it was the murder weapon. Seven members of gang $B$ were seen in the area of the knifing immediately after the crime, although no witnesses to the crime are available. In that situation, it might be sensible, under the rationale of Davis and the balance test, to allow the issuance of a single warrant to permit the fingerprinting of those seven individuals.

\section{B. Grand Juries}

Although not police investigatory detentions, grand jury investigations present problems similar to Davis. In United States v. Dionisio, ${ }^{137}$ for example, the grand jury subpoenaed 20 wituesses to obtain voice exeinplars, apparently to identify various voices on tapes in the grand jury's possession. ${ }^{138}$ Despite the similarity to the police detention problem, in Dionisio and its companion case, United States $v$. Mara ${ }^{139}$ which dealt with handwriting sainples to be obtained from one individual, the Court completely failed to provide the kinds of protection which Davis apparently had promised.

The main point of Davis, presumably, is that the government can not randomly subject any citizen to an imvestigative technique, even one that involves a relatively limited privacy invasion. Thus, for nonconsensual fingerprinting to be proper, the prior screening of a warrant articulating at least some probability standard is necessary. In Dionisio-Mara, however, merely because the investigation was undertaken by a grand jury, the Court rejected the need for this protection.

135. 394 U.S. at 727.

136. Id. at 728 .

137. 93 Sup. Ct. 764 (1973).

138. Id. at 766 .

139. 93 Sup. Ct. 774 (1973). 
Although perceiving that the privacy problem resulted not merely from the giving of the voice or handwriting samples, but from the very fact that the individuals involved were required to appear before the grand jury, ${ }^{140}$ the Court concluded that a subpoena to appear before a grand jury is not a "seizure" in the fourth amendment sense, "even though that summons may be inconvenient and burdensome."141 Yet government action which substantially burdens or inconveniences individuals significantly infringes on privacy and thus creates a cognizable fourth amendment invasion. ${ }^{142}$

The Court's suggestion that citizens in general "are not constitutionally immune" from assisting grand jury proceedings ${ }^{143}$ is an inadequate explanation for excluding fourth amendment protection, for in no fourth amendment situation is the citizen completely insulated from government interference. Another apparent rationale for the Court's position is that grand jury activity is such an innocuous privacy invasion that no protection is required. Quoting Judge Friendly's opinion in United States v. Doe (Schwartz), ${ }^{144}$ the 1najority in Dionisio states that a coinpelled appearance before a grand jury lacks the stigma of a police arrest, and is of limited inconvenience because the time can be arranged in advance. ${ }^{145}$ Although there is some valididty to the latter consideration, to confidently argue that no stigma attaches to a compelled appearance before a grand jury, which by definition is dealing with criminal activity, is naive at best. ${ }^{146}$

More significantly, the Court rather casually characterizes the grand jury as an historically neutral body "whose mission is to clear the innocent, no less than to bring to trial those who may be guilty,"147 thus completely ignoring the extensive criticism of the grand jury's gross deviation fron its origial mission. ${ }^{148}$ The grand jury, far from being neutral, has become a strategic aid to the prosecution in case

140. The Court correctly saw the compelled appearance as a "'seizure' of the "person" " separate from the search for evidence. 93 Sup. Ct. at 769 . This is consistent with the view which the court of appeals took of the detention of the package in Van Leeuwen, although perhaps in conflict with the Supreme Court's statements in Van Leeuwen on the same subject. See text accompanying note 121 supra.

141. 93 Sup. Ct. at 769 (emphasis added).

142. See notes 86-88 supra and accompanying text.

143. 93 Sup. Ct. at 769, quoting Branzburg v. Hayes, 408 U.S. 665, 682 (1972).

144. 457 F.2d 895,898 (2d Cir. 1972).

145. 93 Sup. Ct. at 770 .

146. See 93 Sup. Ct. at 781 (Marshall, J., dissenting).

147. Id. at 773 .

148. See L. Katz, L. Litwin, and R. Bamberger, Justice is the Crme 187 (1972) [hereinafter cited as KATZ ET AL.]; Boudin, The Federal Grand Jury, 61 Gzo. L.J. 1, 24-25 (1972); Comment, 7 HARv. Civ. RIGrTs-Civ. LIB. L. REv. 432, 440-41 (1972). Justice Douglas makes the point explicitly in his dissent. 93 Sup. Ct. at 777. 
preparation, ${ }^{149}$ and rather than screening out "the innocent," functions mainly as a rubber stamp for prosecutorial decisions. ${ }^{150}$ Furthermore, the grand jury has become an institution with enormous abuse potential. The government retaims the power to choose an imconvenient situs $^{151}$ and has the ability to subject the witness to harassing interrogation. ${ }^{152}$ Furthermore, this potential for harassment is continuing, unlike the fingerprinting technique involved in Davis. Additionally, grand jury abuse has first amendment implications, as well as the typical fourth amendment privacy considerations. The fear that grand jury harassment has been utilized to discourage participation in politically dissident groups has been advanced by a number of commentators. ${ }^{153}$ It is difficult to imagine how the Court could so thoroughly ignore these considerations of governmental intrusion so clearly relevant to determining the need for fourth amendment protection.

Even Justice Marshall, dissenting from the Court's resolution, appears not to have fully appreciated the problem. Justice Marshall accepts the government's right to subpoena grand jury witnesses to testify without fourth amendment strictures because of his belief that there is a limited danger for grand jury abuse when only testimony is being elicited in light of the witnesses' fifth amendment right to refuse to answer incriminating questions..$^{154}$ Unfortunately, this analysis ignores the difficulties that may exist in distinguishnig "witnesses" froin "defendants" in order to determine whether a fifth amendinent claim can be validly made, ${ }^{155}$ and fails to recognize that only use iminunity need be granted ${ }^{156}$ before a witness can be compelled to give self-incriminating testimony. ${ }^{157}$ More importantly, the analysis fails to recognize that the very appearance of the witness before the jury, with the attendant "testimonial" questioning, constitutes a significant governmental invasion. Once the witness has gone through that much of the

149. KATZ ET AL., supra note 148, at 187; Boudin, The Federal Grand Jury, supra note 148.

150. Katz et al., supra note 148, at 15; Comment, 7 Harv. Civ. Riohts-Civ. Lib. L. REv., supra note 148, at 440-41; 3 LoY.-CHI. L.J. 305, 311 (1972).

151. Comment, 7 Harv. Crv. Rights-Civ. LIB. L. Rev., supra note 148, at 452.

152. Boudin, The Federal Grand Jury, supra note 148, at 4, 20.

153. See, e.g., Boudin, The Federal Grand Jury, supra note 148; Comment, 7 HaRv. Civ. Rights-Crv. LIB. L. Rev., supra note 148; Fosburgh, Who Is Guy Goodwin and Why Are They Saying Those Terrible Things About Him?, 3 JURIS DocroR 14, 17-18 (January, 1973).

154. 93 Sup. Ct. at 788.

155. Boudin, The Federal Grand Jury, supra note 148 at 2.

156. Kastigar v. United States, 406 U.S. 441 (1972).

157. Boudin, The Federal Grand Jury, supra note 148, at 14-15; 7 HaRv. Civ. Rights-Civ. Lib. L. Rev., supra note 148, at 437. 
process, the requirement of a handwriting sample will probably seem innocuous by comparison. ${ }^{158}$

Accepting that the fourth amendment is applicable to grand jury proceedings, ${ }^{159}$ the problem agaim becomes determining an adequate level of protection that responds both to the requirements and to the dangers of this government action. The rather substantial privacy invasion caused by compelled grand jury appearances suggests that the government should be required to fulfill a relatively stringent standard of probability. In Mara, the Supreine Court noted the standard articulated by the court of appeals, ${ }^{\mathbf{1 6 0}}$ which had concluded that fourth amendment protection was necessary, and required the government to show by affidavit "that the grand jury investigation was properly authorized, for a purpose Congress can order, that the information sought is relevant to the imquiry, and that the grand jury's request for exeinplars is 'adequate, but not excessive, for the purposes of the relevant imquiry." "161 The court of appeals imterpreted "adequate but not excessive" to inean that "the government inust affirmatively show that the grand jury process is not being abused."162 This standard bears substantial resemblance to the requirements expressed in Camara and the initial requirement herein suggested for the regulatory search and welfare search situations, but lacks any requirement that the government show a likelihood that an individual or group of individuals summoned before the grand jury, will be able to aid the investigation. If the court's "process is not being abused" language aims at this problem, it does so in a vague and easily evaded manner. Given the close similarity of the problems presented by "dragnet" fishing for fingerprints by the police and for voice or handwriting samples by the grand jury, at the least the reasonable belief standard intimated in Davis should be required..$^{163}$

The extensive, continuing harrassment potential of a grand jury investigation, however, requires that other citizen protections be added where practically feasible. One possibihty, suggested by Mr. Justice

158. The majority in Dionisio seemed to recognize this fact. 93 Sup. Ct. at 773 n.14.

159. In Hale v. Henkel, 201 U.S. 43 (1906), the Supreme Court struck down the use of an overly broad subpoena duces tecum on fourth amendment grounds. The Court in Dionisio apparently held Hale mapplicable because it involved a quest for books and papers, not testimony, 93 Sup. Ct. at 770, 772 n.13, a distinction that might have been tenable in 1906, when the historical role of the grand jury was considerably more viable than it is today.

160. In re September 1971 Grand Jury (Mara), 454 F.2d 580 (7th Cir. 1971).

161. Id. at 584-85.

162. Id.

163. Justice Douglas, dissenting, made clear that, for him at least, less than traditional probable cause could suffice. 93 Sup. Ct. at 780. 
Douglas, dissenting, is to require an adversary hearing to determine whether reasonable behief exists. ${ }^{164}$ The prospective witness will have notice of the government action in any event, and surprise is not a factor. Since the essential privacy invasion flows merely from being before the grand jury, an after-the-fact determination that the compelled appearance was wrongful may be little solace to the citizen.

The problem this presents is that the requirement of such a prior adversary hearing may greatly undermine the utility of the grand jury. What must be remembered, however, is that in most instances grand juries will be hearing from victims of or witnesses to crimes who will be quite willing to appear. Thus only a sinall percentage of grand jury investigations will be delayed by a prior adversary hearing procedure, and these are exactly the situations where the delay nust be tolerated to determine whether the harassment issue is valid.

Teinporary detention, compelled submission to "scientific" police inquiry, and compelled appearance before a grand jury thus present particularly apt situations for apphication of balancing primciples in the criminal investigation area. Eventual application of these principles, however, will require more precise judicial analysis than the Court has thus far provided..

$\mathrm{V}$.

\section{CONCLUSION}

Since the decisions in Camara-See and Terry, the Supreme Court's use of the balancing test has not been encouraging. The Court's rationale in Wyman, although perhaps not the result, raises at least soine question as to whether the theory is even viable. In Biswell, the Court at least mentioned the Camara requirements, although its analysis was shallow. In Dionisio-Mara, the Court, by its reference to the limited stigma and privacy invasion of a coinpelled grand jury appearance, again gave lipservice to the balancing theory, but its application was unrealistic. And it is hard to explain Van Leeuwen except as an application of the balancing test, although the Court, without explaining why, has opted for temporary detention only in the situation there presented.

The need for flexible procedures and the difficulty the Court seems to be having in dealing with the balance test on a case-by-case basis at least to some extent argues for legislative action in the selection of appropriate procedures. ${ }^{165}$ Certainly there is no reason why

164. Id.

165. E.g., ARIz. Rev. STat. \& 13-1424 (West Supp. 1972). Virtually the same end is achieved if a court adopts a procedure as part of its rule-making power. See 
legislative attempts to implement the balancing theory should not be encouraged. Yet the wide and variant range of potential problems which are presented by fourth amendment cases, and which may be solved only by a flexible use of the balancing approach, makes thorough before-the-fact legislative solution unlikely.

Also, it is necessary to recognize the danger that the balancing theory can be used to balance away important fourth amendment protections. ${ }^{106}$ Arguably, even if balancing government need against citizen imterests in order to define proper procedure is sound in theory, in practice it may result in citizens receiving substantially less protection of their civil liberties than they lad under an absolutist view of the fourth amendment, largely because courts seem to accept government rationales for reducing citizen protection without close scrutiny. Thus far the Supreme Court has tended to ignore citizen needs even while giving lipservice to the balancing test. In Biswell, for example, although the Court spoke in the language of Camara, citizens were given no protection at all. However, it is not fair to assume that courts will always improperly use the balancing test. Furthermore, there is no reason to believe that if the only options are full protection or no protection, courts will choose the former, despite government insistence that its enforcement needs are being defeated. Unfortunatley, just the opposite is likely to occur. In all likelihood the result in Biswell would have been the same in the absence of Camara. The Court merely would have reasoned, as it did in Frank, that the fourth amendment did not operate against noncriminal searclies. Likewise, the Court's imconsistent treatment of vehicle search cases does not inspire confidence in its commitment to proteet civil hiberties.

The balancing test, lowever, if used thoughtfully, permits compromises, and may, in many situations, result in citizens receiving some useful protection against government intrusion, instead of none at all. Unfortuately, since Camara and Terry, the Supreme Court has failed to analyze thoughtfully or make imaginative use of the balancing test's potential. Without this effort on the part of the Court, the balance of interests approach will be of limited utility in meeting fourth amendment problems.

proposed Federal Rules of Criminal Procedure, Rule 41.1, discussed in detail in Note, 72 COLUM. L. REv. 712 (1972).

166. See Kitch, The Court's Code of Criminal Procedure: 1968-1969 Edition, supra note 134, at 168-72; Foote, The Fourth Amendment: Obstacle or Necessity in the Law of Arrest?, 51 J. CRIM. L.C. \& P.S. 402 (1960). 


\title{
California Law Review
}

VoL. 61 JUNE 1973 No. 4

\section{BOARD OF EDITORS}

\section{2-1973}

\author{
Editor in Chief \\ Staphen L. Kostka \\ Managing Editor \\ STEPHEN JULIAN YODER
}

Notes \& Comments

Kevin F. KelLY

WIIIIAM F. CAPPS

Crajg H. Casebeer

Mark S. Dodson

DAVID GOLDBERG

ANN FINGARETTE HASSE

LEsLIR ANN JoHNSON

RAYMond D. PIRE

Craig D. MILLER

JOHN E. THORSON
Managing

Gabrielle R. CAMPBeLL

JAMES DRUMMY

Peter Grossman

Projects

JEFFREY M. ALLEN

JOSEPH DiCtuccio

Associate Editors

Susan Frelich APPLETON

AJICE M. BEASLEY

MICHAEI J. BERTINETTI

Christopher C. Calkins

Raymond A. Diaz

PAUL E. DORROH

KENNETH J. FISHBACH, JR.
ERNESTINE FORREST

HowARD W. Foss, JR.

David M. GLASS

KeLLY GUEST

JACK H. KAUFMAN, JR.

LARY LAWRENCE

\footnotetext{
Administrative Assistant

Patricta G. SMTth
}

Articles \& Book Reviews

Ira Mark Ellman

MICHAEI J. BAKER

Marsha Siegel Berzon

DAVID F. BOYLE

Supreme Court

PAIMER BROWN MAdDEN

Research

Steven S. BeLL

RICHARD KALISH

DANTEL J. LEER

Camille E. LeGrand

Charles H. Matthews, Jr.

Thomas E. RaNKIN

Lee Charles Rosenthal

Crato M. Thomas

Martin J. Thompson 


\section{California Law Review}

\begin{tabular}{lll}
\hline VoL. 61 & JUNE 1973 & No. 4 \\
\hline
\end{tabular}

\section{BOARD OF EDTTORS}

\section{3-1974}

Editor in Chief

CHRISTOPHER H. SCHROEDER

Executive Editor

E. Elizabeth Summers
Managing Editor

RANDALL IRA BARKAN

Managing

MARY M. Logalbo

Research

ELIOT S. JUbELIRER

Thom Greenfield Seaton

Patrick W. Walsh

SUSAN SAWYER

Thomas S. WiLliamson, JR.

\section{Associate Editors}

Charles Frederick Adams JAMES A. AsEEW

PaUl Clark

GARY JAY COHEN

PhIIIP R. Diamond

JOHN A. GLOGER

DOUglas L. HAMMER

MARTIN WAYNe JoHNSON
ROBERT L. LAWRENCE

PETER LOMHOFF

RANDALI R. MCCATHREN

Alan MItTMan

Lise A. Pearlman

LARRY PEITZMAN

JOSEPH P. POWERS

Administrative Assistant

PATRICIA G. SMITH
JAMES D. RICHMAN

HENRY SHIELDS, JR.

Scott Sonne

NANCY E. SULLIVAN

ANNe MCLeOD TrebiLCOCK

Catalina Valencta

DaVID L. WAGNER

ROBERT E. WILLETT 